\title{
Computer-based nursing education: An integrative review of empirical studies
}

\author{
J uan Manuel Carrillo de Gea ${ }^{1}$, J osé Luis Fernández Alemán ${ }^{1}$, Ana Belen Sánchez García² \\ 1. Dept. Informática y Sistemas, Facultad de Informática, Universidad de Murcia, Murcia, Spain 2. Hospital General \\ Universitario Reina Sofía, Murcia, Spain.
}

Correspondence: Juan M. Carrillo de Gea. Address: Dept. Informática y Sistemas, Facultad de Informática, Campus Universitario de Espinardo 30100, Espinardo, Murcia, Spain. Telephone: 34-868-884-642. E-mail: jmcdg1@um.es

Received: December 12, 2011

Accepted: January 30, $2012 \quad$ Published: August 1, 2012

DOI : $10.5430 /$ jnep.v2n3p162

URL: http://dx.doi.org/10.5430/jnep.v2n3p162

\begin{abstract}
The goal of this study is to explore the ways in which Computer-Based Nursing Learning (CBNL) has been studied and the findings that have been made with regard to its use in undergraduate nursing education. We undertook an integrative review by selecting papers published in English between 2007 and 2010. We included in the review empirical studies comparing CBNL with other training strategies for clinical skills education in the context of undergraduate nursing education. We carried out an electronic search in which specific keywords were used, and a total of 467 citations were found. Nine of these studies met the inclusion criteria. A list of criteria for evaluating the quality of the empirical studies identified was also used. With regard to the impact of CBNL on skill performance and cognitive recall, the results were positive since most studies reported higher skill and knowledge scores using CBNL. Only two studies tested skill or cognitive retention. Seven studies reported high levels of students' satisfaction with CBNL. However, the authors identified some problems related to technical issues in four studies. Finally, we described and criticized the experiences, since important weaknesses in the experimental designs were detected. We also provided some recommendations for better practices in the research methods.
\end{abstract}

\section{Key words}

Clinical skills, Computer-based learning, Integrative review, Nursing education, Undergraduate students

\section{Introduction}

There is a certain amount of concern at an international level that nurses experience important deficits upon attaining their qualifications ${ }^{[6]}$. Innovative learning methods are gaining popularity as an alternative means of providing education in clinical skills, but they require solid and effective research.

Some authors ${ }^{[2,4,6,8,30,31]}$ attributed many benefits to the use of ICTs (Information and Communication Technologies) in the context of nursing education - although all of these depends on the instructional design of the learning experience and the resources available to both the instructor and the student: (i) temporal flexibility; (ii) spatial decentralizing; (iii) collaboration and communication; (iv) development of computer-literacy skills; (v) students' self-direction, motivation, satisfaction and enjoyment; (vi) safe environments; (vii) repeated demonstrations; (viii) use of online databases to keep up-to-date with current research; (ix) accommodation to different styles of learning and (x) shortening of 
the instructional time. There are also some barriers which may lead to the failure of the online learning process: (i) the loss of the social process of learning; (ii) technical and educational support and (iii) training in computer use and certain technical knowledge to carry out the online activities.

In this paper, we present an integrative review of the literature related to proposals concerning Computer-Based Nursing Learning (CBNL) in colleges and universities. This survey identifies several undesirable flaws that well-conducted research studies should avoid. We consequently outline certain recommendations on how to confront new experiences in computer-based nursing education.

When discussing the use of computers in nursing education, there is vagueness in definition and terminology. We will follow the usage adopted by each author, and will ourselves use the term CBNL to refer to this area.

\subsection{Background and rationale}

In view of the literature examined, we identified four stages in the evolution of CBNL in nursing ${ }^{[21,31]}$ : (i) the use of text-mode systems before 1980; (ii) the combination of text and limited graphics from the early 1980s to the mid-1990s; (iii) the use of highly advanced systems from the mid-1990s to the mid-2000s and (iv) the introduction of virtual reality to master technical skills in virtual clinical settings from the mid-2000s until today.

A previous systematic review of e-learning for health professionals and students ${ }^{[10]}$ identified eight structural prerequisites for the delivery of successful e-learning programs: organizational, economics, hardware, software, support, pedagogical, psychological, and skills. However, if an effective delivery of learning activities is to be achieved, these structural issues should be accomplished through the use of a variety of e-learning techniques: online and face-to-face induction programs, discussion forums, group work, high-quality educational material, case studies and scenarios, printable materials, discussion-group supported by tutors, and regular assessments ${ }^{[8]}$.

Lewis et al. ${ }^{[21]}$ evaluated 25 studies published between 1966 and 1998, and reported on the impact of computer-based learning packages in nursing on learning, when compared with conventional instruction methods. These authors identified a list of common design flaws such as small or non-specified sample size, non-specified experimental design, a lack of random assignment and quantitative data, insufficient time for completion of material, doubtful reliability and validity of the research instruments, amongst others. Bloomfield et al. ${ }^{[6]}$ identified and reviewed 12 studies published between 1997 and 2006, and again found important weaknesses in designs. The authors concluded that sample size, range of skills, longitudinal follow-up and control of confounding variables are areas which should be addressed in future studies. As pointed out by these authors, the design flaws made it difficult to derive firm conclusions about the effectiveness of CBNL.

More recently, a systematic review focused on which e-learning techniques most enhance the learning of health professionals in the United Kingdom ${ }^{[8]}$. The authors of this paper identified a total of 19 studies (eight of them relating to the delivery of e-learning programs to nurses, midwives, and allied professions). In another systematic review, Al-Jewair et al. ${ }^{[3]}$ compared the efficacy and time efficiency of CBNL with conventional learning methods or no instruction in endodontics education. Seven randomized controlled trials met the inclusion criteria. No conclusions were made with regard to students' performance during clinical procedures or the cost-effectiveness of CBNL.

At this point, the study presented herein provides an updated integrative review of research works regarding the comparison of CBNL with conventional teaching methods on clinical skills education.

\subsection{The review}

\subsubsection{Aim}

The goal of this paper is to prepare a review on the research investigating the use of computer-based learning for nursing education. The objective of this review is to answer the following questions: 
1) How has CBNL for nursing education been studied between 2007 and 2010 ?

2) What findings have been made with regard to the use of CBNL in undergraduate nursing education?

3) What research practices should be improved in future studies?

\subsubsection{Design}

We undertook an integrative review, since it would provide an instrument with which to understand the literature on a particular topic by describing the key issues. The review presented in this paper follows the PRISMA reporting standard ${ }^{[24]}$. Figure 1 shows a PRISMA flow diagram that summarizes this process.

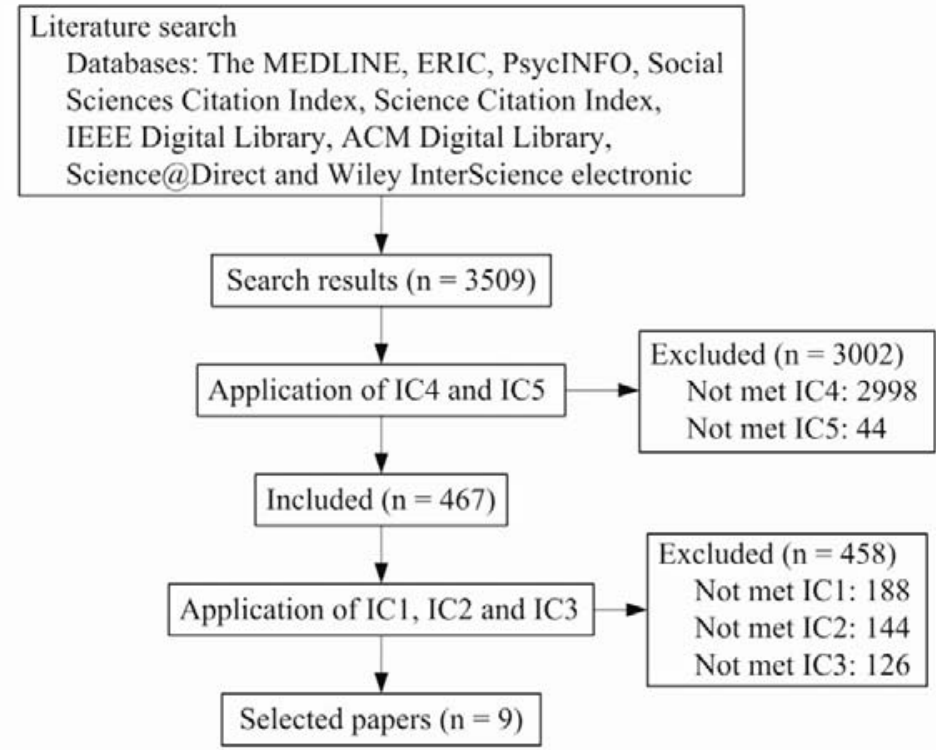

Figure 1. PRISMA Flow Diagram

\section{Search methods}

The selection of the studies was organized in four steps:

1) We conducted a search for publications in the electronic database related to health and computer science (see Table 1): The MEDLINE, ERIC, PsycINFO, Social Sciences Citation Index, Science Citation Index, IEEE Digital Library, ACM Digital Library, Science@Direct and Wiley InterScience. We used some of the terms identified by Adams ${ }^{[1]}$ and Glen ${ }^{[15]}$ to describe the use of computers in nursing education. Table 1 shows the general terms and keywords related to the focus of the review, specific descriptors from the thesaurus of each database (e.g. Medical Subject Headings (MeSH) and Health Sciences Descriptors for MEDLINE) that we used in the search. We also added acronyms and hyphenated words to the search string. The procedure was then suitably adapted to the search engine features of each digital library. Two authors initially conducted searching in early 2010, and repeated it on a regular basis during such year to ensure that the study considered each new piece of research discussing the topic.

2) We screened the title and abstract of the papers in order to confirm their relevance and adopt the exclusion and inclusion criteria presented in Table 1. 
3) Two authors read the papers fully or partially in light of their relevance to the focus of the review when more information was required to discover whether the study met the inclusion criteria.

4) One author carried out citation tracking and scrutiny of reference lists to find additional papers.

Table 1. Electronic databases. Search outcome. Terms and keywords used in search. Inclusion and exclusion criteria (modified from Bloomfield et al. ${ }^{[6]}$ ). PF: Publications Found; SSCI: Social Sciences Citation Index; SCI: Science Citation Index; ICx: Inclusion Criterion

\begin{tabular}{llc}
\hline Database & Characteristics and \# publications & \# PF \\
\hline MEDLINE & Medical Literature Analysis and Retrieval System Online. 19,000,000 records from 1966 & 290 \\
ERIC & Education Resources Information Centre. 1,300,000 records education-related materials & 18 \\
PsycINFO & Abstract database related to psychology. 2,800,000 records & 13 \\
SSCI and SCI & Interdisciplinary citation index. 17,000,000 records & 94 \\
IEEE Digital Library & The Institute of Electrical and Electronics Engineers. 2,500,000 records from 1963 & 29 \\
ACM Digital Library & The Association for Computing Machinery. 1,000,000 records from 1947 & 1 \\
Science@Direct & Engineering and Health Sciences. Operated by the publisher Elsevier. 10,000,000 records & 14 \\
Wiley InterScience & Global academic publishing company. 3,000,000 records & 8
\end{tabular}

\begin{tabular}{|c|c|c|}
\hline \multicolumn{3}{|c|}{ Search string } \\
\hline \multicolumn{3}{|c|}{$\begin{array}{l}\text { nursing AND (“computer assisted instruction” OR “computer-assisted instruction” OR “computer aided instruction” OR “computer-aided } \\
\text { instruction” OR CAI OR “computer based learning” OR “computer-based learning” OR CBL OR “computer based training” OR } \\
\text { “computer-based training” OR CBT OR “programmed instruction” OR “programmed learning” OR “computer mediated education” OR } \\
\text { “computer-mediated education” OR CME OR “computer facilitated teaching” OR “computer-facilitated teaching” OR “computer } \\
\text { facilitated learning” OR “computer-facilitated learning” OR CFL OR “web based learning” OR “web-based learning” OR WBL OR } \\
\text { "internet learning” OR “electronic learning” OR e-learning OR “interactive multimedia learning” OR IML OR “online learning” OR } \\
\text { "computer assisted learning” OR “computer-assisted learning” OR “computer aided learning” OR “computer-aided learning” OR CAL) }\end{array}$} \\
\hline Code & Inclusion & Exclusion \\
\hline IC1 & $\begin{array}{l}\text { The use of CAL for clinical skills } \\
\text { education in the context of } \\
\text { undergraduate nursing education }\end{array}$ & $\begin{array}{l}\text { The use of CAL for clinical skills education in the context of non-undergraduate nursing } \\
\text { education or in other health disciplines or patient education or faculty education or not } \\
\text { involving clinical skills education or to gain theoretical knowledge in nursing. The use of } \\
\text { simulators and games in nursing education }\end{array}$ \\
\hline IC2 & $\begin{array}{l}\text { Empirical studies comparing CAL } \\
\text { with other educational strategies } \\
\text { for clinical skills education }\end{array}$ & $\begin{array}{l}\text { Descriptive reports, discussion papers or literature reviews summarising the development of } \\
\text { CAL materials or research that evaluated students, professionals or staff perceptions or the } \\
\text { quality of CAL in nursing learning or teaching. The use of technology resources to engage } \\
\text { students in the classroom }\end{array}$ \\
\hline IC3 & $\begin{array}{l}\text { Empirical studies exploring the } \\
\text { effect of CAL on educational } \\
\text { outcomes }\end{array}$ & Empirical studies evaluating CAL exclusively on learner satisfaction, opinion or profile \\
\hline IC4 & $\begin{array}{l}\text { Papers published between } 2007 \\
\text { and } 2010\end{array}$ & Papers published before 2007 \\
\hline IC5 & Papers published in English & Papers published in languages other than English \\
\hline
\end{tabular}

We retrieved the references related to the focus of the review through the use of various electronic information sources from institutional subscriptions to the University of Murcia. These totalled over 20 million publications in international conferences, journals and events of nursing community. We selected Google Scholar and Microsoft Academic Search to find grey literature in the area.

\subsection{Search outcome}

First, the authors found a total of 467 citations through an electronic search by using the keywords and the criteria IC4 and IC5 shown in Table 1. After applying the rest of the inclusion criteria presented in Table 1, we selected nine empirical studies related to CBNL. A citation tracking and a scrutiny of reference lists did not yield any additional hits. Note that 
these papers were found in more than one electronic database. Two reviewers selected most of the papers, with a satisfactory inter-rater reliability of 0.9 .

\subsection{Quality appraisal}

We used a list of criteria for evaluating the quality of the empirical studies identified. We employed the criteria proposed by Lewis et al. ${ }^{[21]}$ and later adopted by Bloomfield et al. ${ }^{[6]}$ so that comparisons could be made with this earlier work. Eight of the nine selected papers were published in journals, and the one remaining paper was presented in a conference. Of the eight papers published in journals, seven were issued in four journals indexed in the Journal Citation Reports and MEDLINE (Nurse Education Today, Journal of Clinical Nursing, International Journal of Nursing Studies and Journal of Nursing Education), and one paper was issued in a non-indexed journal.

\subsection{Data abstraction and synthesis}

We gathered the data from the nine scientific papers selected, and designed a template to support the integrative review according to the following fields:

- Study details: A. Author, date and country; B. Aim.

- Research design: C. Ethical considerations; D. Pre-test-post-test design; E. Academic level and recruitment strategy; F. Demographic report; G. Size and comparative interventions; H. Types of computerised technologies; I. Clinical skills.

- Findings: J. Results in skill performance, cognitive recall, knowledge acquisition, knowledge and skill retention; K. Student satisfaction; L. Identified problems.

\section{Results}

In this section, the results of the review are organized in three subsections: study details, research instruments and measures, and main findings.

\subsection{Study details}

The nine papers selected in the integrative review were published between 2008 and 2010 (three in 2008, five in 2009 and one in 2010) from eight countries, the majority being from Europe ${ }^{[4,5,18,29]}$, Asia ${ }^{[14,17,22]}$, one from America ${ }^{[19]}$ and one from Australia ${ }^{[12]}$. The aims of these studies are shown in Table 2.

All of the studies reported the use of a post-test and seven of these reported the use of a pre-test ${ }^{[4,5,12,14,17,18,22]}$. Participants in seven studies were second-year ${ }^{[12,17,22,29]}$ or third-year ${ }^{[4,14,19]}$ nursing undergraduates at colleges or universities. Two studies involved first-year ${ }^{[5,18]}$ nursing students. In almost all the studies, the students were randomly divided into experimental and control groups; only one study ${ }^{[29]}$ did not report that this procedure had been carried out. The studies varied widely in size, ranging from a sample size of $10^{[18]}$ and $17^{[19]}$ to $232^{[5]}$ recruits. Nevertheless, seven of the reviewed studies ${ }^{[4,5,12,14,17,22,29]}$ reported a sample of more than 70 participants.

Four of the studies ${ }^{[14,17,19,22]}$ compared a blended learning approach with a conventional teaching method (lecture, demonstration and tutorial). The remaining studies ${ }^{[4,5,12,18,29]}$ compared an online learning style with a conventional learning approach. One study ${ }^{[17]}$ described the use of three comparative interventions: two blended approaches and one conventional learning method based on lectures and demonstrations.

Most of the studies ${ }^{[4,5,14,17,18,22]}$ used multimedia applications, which principally included videos. One study used an e-learning program ${ }^{[29]}$, but the specific type of technology resource was not identified. Two studies ${ }^{[12,19]}$ used mobile devices such as PDAs. 
Table 2. Research design

\begin{tabular}{|c|c|c|c|c|}
\hline $\begin{array}{l}\text { Author, date and } \\
\text { country }\end{array}$ & Aim & $\begin{array}{l}\text { Pre-test- } \\
\text { post-test design }\end{array}$ & $\begin{array}{l}\text { Size and comparative } \\
\text { interventions }\end{array}$ & $\begin{array}{l}\text { Types of computerised } \\
\text { technologies }\end{array}$ \\
\hline $\begin{array}{l}\text { Beeckman et al. }{ }^{[4]} \text {; } \\
\text { Belgium }\end{array}$ & $\begin{array}{l}\text { To detect problems when classifying } \\
\text { pressure ulcers and to examine whether an } \\
\text { e-learning program is able to increase the } \\
\text { classification skills of qualified nurses and } \\
\text { nursing students }\end{array}$ & $\begin{array}{l}\text { One pre-test and } \\
\text { three post-tests }\end{array}$ & $\begin{array}{l}\text { A. The experimental } \\
\text { intervention ( } \mathrm{n}=103 \text { ) } \\
\text { consisted of a 1-hour session } \\
\text { with an e-learning program. } \\
\text { B. The control intervention } \\
\text { ( } \mathrm{n}=111 \text { ) consisted of a 1-hour } \\
\text { lecture }\end{array}$ & $\begin{array}{l}\text { The "PUCLAS2" e-learning } \\
\text { program to classify pressure } \\
\text { ulcers using definitions and } \\
\text { high quality photographs and } \\
\text { video }\end{array}$ \\
\hline $\begin{array}{l}\text { Bloomfield et al. }{ }^{[5]} \text {; } \\
\text { UK }\end{array}$ & $\begin{array}{l}\text { To test whether nursing students could learn } \\
\text { and retain the theory and skill of } \\
\text { hand-washing more effectively when taught } \\
\text { using CAL compared with conventional } \\
\text { face-to-face methods }\end{array}$ & Four time points & $\begin{array}{l}\text { A. The intervention group } \\
\text { ( } \mathrm{n}=118) \text { used an interactive, } \\
\text { multimedia, self-directed } \\
\text { CAL module. } \\
\text { B. The control group ( } \mathrm{n}=113 \text { ) } \\
\text { was taught by an experienced } \\
\text { lecturer. }\end{array}$ & $\begin{array}{l}\text { A self-directed CAL module } \\
\text { with: animated multimedia, } \\
\text { high quality photographs and } \\
\text { links to relevant websites }\end{array}$ \\
\hline $\begin{array}{l}\text { Farrell and Rose }{ }^{[12]} \text {; } \\
\text { Australia }\end{array}$ & $\begin{array}{l}\text { To investigate whether the use of PDAs } \\
\text { enhanced nursing students' } \\
\text { pharmacological knowledge in the } \\
\text { medical-surgical practice. To examine the } \\
\text { influence of PDAs on how nursing students } \\
\text { contextualize medical-surgical nursing } \\
\text { knowledge. }\end{array}$ & Pretest and post-test & $\begin{array}{l}\text { A. An experimental group } \\
\text { ( } \mathrm{n}=41 \text { ) used a PDA (3-week } \\
\text { medical-surgical clinical } \\
\text { placement). } \\
\text { B. A control group ( } \mathrm{n}=35) \\
\text { completed a similar clinical } \\
\text { placement without access to a } \\
\text { PDA }\end{array}$ & $\begin{array}{l}\text { PDAs and pharmacology } \\
\text { database }\end{array}$ \\
\hline $\begin{array}{l}\text { Gerdprasert et al. }{ }^{[14]} \text {; } \\
\text { Thailand }\end{array}$ & $\begin{array}{l}\text { To develop a web-based learning media on } \\
\text { the process and mechanism of labour for } \\
\text { third-year university nursing and midwifery } \\
\text { students. }\end{array}$ & $\begin{array}{l}\text { Pre-test and } \\
\text { post-test }\end{array}$ & $\begin{array}{l}\text { A. An experimental group } \\
\text { ( } \mathrm{n}=42) \text { received lecture } \\
\text { supplemented with a } \\
\text { web-based unit for } 2 \text { weeks } \\
\text { (blended approach). } \\
\text { B. A control group ( } \mathrm{n}=43 \text { ) } \\
\text { received only lecture }\end{array}$ & $\begin{array}{l}\text { A web-based learning unit } \\
\text { (stages of labour shown } \\
\text { graphically, animation of } \\
\text { mechanism of labour, a video } \\
\text { on early breast feeding, } \\
\text { interactive quizzes and } \\
\text { exercises) }\end{array}$ \\
\hline $\begin{array}{l}\text { Kaveevivitchai et al. } \\
\text { [17]; Thailand }\end{array}$ & $\begin{array}{l}\text { The authors have developed a CAL } \\
\text { multimedia on vital signs with animation } \\
\text { and audio features for teaching in the } \\
\text { classroom based on the 5Es inquiry cycle }\end{array}$ & $\begin{array}{l}\text { Pre-test and } \\
\text { post-test }\end{array}$ & $\begin{array}{l}\text { A. CAL/lecture }(\mathrm{n}=37) \text {. } \\
\text { A blended approach. } \\
\text { B. AL/lecture/demonstration } \\
(\mathrm{n}=40) \text {. A blended approach. } \\
\text { C. lecture/demonstration } \\
(\mathrm{n}=40)\end{array}$ & $\begin{array}{l}\text { The CAL multimedia whose } \\
\text { content was displayed by using } \\
\text { graphics, pictures, animation, } \\
\text { video and simulation of } \\
\text { experiences }\end{array}$ \\
\hline Kelly et al. ${ }^{[18]}$; Ireland & $\begin{array}{l}\text { To detect problems when classifying } \\
\text { pressure ulcers and to examine whether an } \\
\text { e-learning program is able to increase the } \\
\text { classification skills of qualified nurses and } \\
\text { nursing students }\end{array}$ & $\begin{array}{l}\text { Experimental } \\
\text { post-test }\end{array}$ & $\begin{array}{l}\text { A. Experimental group } \\
(\mathrm{n}=6) \text { : videos. } \\
\text { B. Control group }(\mathrm{n}=4) \text { : } \\
\text { lecturer demonstration, } \\
\text { practice under supervision }\end{array}$ & Instructional videos \\
\hline $\begin{array}{l}\text { Kenny et al. }{ }^{[19]} \text {; } \\
\text { Canada }\end{array}$ & $\begin{array}{l}\text { To evaluate whether the implementation of } \\
\text { mobile devices in a nursing education } \\
\text { setting would be feasible and practical, and } \\
\text { to assess whether nursing students and } \\
\text { instructors would find the use of such } \\
\text { devices helpful in assisting their learning }\end{array}$ & $\begin{array}{l}\text { One pre-test and } \\
\text { two post-tests }\end{array}$ & $\begin{array}{l}\text { A. A mobile learning } \\
\text { (m-learning) group }(\mathrm{n}=12) \text {. } \\
\text { A blended approach. } \\
\text { B. A comparison group }(\mathrm{n}=5)\end{array}$ & $\begin{array}{l}\text { Discussions in WebCT, and text } \\
\text { and voice communications } \\
\text { using the mobile devices were } \\
\text { conducted at distance }\end{array}$ \\
\hline Lu et al. ${ }^{[22]}$; Taiwan & $\begin{array}{l}\text { To assess the effectiveness of } \\
\text { supplementing conventional classroom } \\
\text { teaching with web-based learning design } \\
\text { when teaching intramuscular injection } \\
\text { nursing skills }\end{array}$ & $\begin{array}{l}\text { Pre-test and } \\
\text { post-test }\end{array}$ & $\begin{array}{l}\text { A. An experimental group } \\
\text { ( } \mathrm{n}=80 \text { ) (blended approach). } \\
\text { B. A control group }(\mathrm{n}=67) \\
\text { learned in a conventional } \\
\text { classroom setting }\end{array}$ & $\begin{array}{l}\text { The Wisdom Master version } 2.4 \\
\text { program, with contents } \\
\text { presented in text, video, and } \\
\text { audio formats }\end{array}$ \\
\hline $\begin{array}{l}\text { Reime et al. }{ }^{[29]} \text {; } \\
\text { Norway }\end{array}$ & $\begin{array}{l}\text { This study looks at, among others: (1) the } \\
\text { relationship between teaching methods and } \\
\text { the score on the multiple choice test (MCT), } \\
\text { (2) the relationship between the study } \\
\text { sources, the number of hours spent studying } \\
\text { and the teaching method. }\end{array}$ & Post-test & $\begin{array}{l}\text { A. An experimental group } \\
\text { ( } n=68 \text { ) used the e-learning } \\
\text { program. } \\
\text { B. A control group ( } n=73 \text { ) } \\
\text { had 3-hour-long lecture }\end{array}$ & An e-learning program \\
\hline
\end{tabular}


The clinical skills investigated varied: health care-associated infections ${ }^{[29]}$, pressure ulcer classification ${ }^{[4]}$, hand-washing procedure ${ }^{[5]}$, intramuscular injection ${ }^{[22]}$, pharmacological knowledge ${ }^{[12,17]}$ integrated anatomical and physiological knowledge of vital signs. One web-based learning approach ${ }^{[14]}$ involved the process and mechanism of labour. The focus of another study ${ }^{[18]}$ was to measure and record a patient's peak expiratory flow rate, teach a patient the correct way to use an incentive spirometer to encourage deep breathing, and the procedure for pulse oximetry. A further study ${ }^{[19]}$ involved a nursing practice education course.

\subsection{Main findings}

With regard to the impact of CBNL on skill performance, the results were positive. Three papers, including those by Beeckman et al. ${ }^{[4]}$, Kaveevivitchai et al. ${ }^{[17]}$ and Lu et al. ${ }^{[22]}$, reported that participants achieved higher skill performance scores when using CBNL in comparison to conventional learning methods. Kelly et al. ${ }^{[18]}$ and Bloomfield et al. ${ }^{[5]}$ found equivalent results in skill performance outcomes. Nevertheless, the latter authors found significant differences in favour of the intervention group by during the 8-week follow-up. One study ${ }^{[29]}$ reported lower skill performance outcomes for students taught using CBNL: the lecture group had a higher sum score in the multiple choice test $(\mathrm{F}(1,138)=3.9, p=.01)$ in comparison to the e-learning group.

The results obtained when considering the effect of CBNL on cognitive recall were also positive. Four studies ${ }^{[12,14,22,29]}$ reported significantly higher knowledge scores in the CBNL group. However, a repeated measure analysis of variance revealed that the results of one of these studies ${ }^{[12]}$ were not statistically significant. No statistically significant differences were detected between the scores of the experimental and control groups in three studies ${ }^{[5,17,18]}$.

Only two studies ${ }^{[4,5]}$ tested skill or cognitive retention. Bloomfield et al. ${ }^{[5]}$ collected baseline data from all participants immediately prior to the teaching intervention. They repeated the knowledge test immediately after the teaching session. Two weeks and eight weeks later, they also assessed hand-washing skills. Significant differences in favour of the intervention group emerged in the 8-week follow-up. On the other hand, Beeckman et al. ${ }^{[4]}$ executed the pre-test, the instruction and the first post-test at the same time and took place one after the other. The second and third post-tests took place after one and two months respectively. The nursing students achieved better results when using the e-learning program. The other studies left one day ${ }^{[17]}$, two days ${ }^{[29]}$, one week ${ }^{[12,18]}$, two weeks ${ }^{[14]}$ or six weeks ${ }^{[22]}$ between instruction and assessment of the knowledge and clinical skill.

Seven of the studies ${ }^{[12,14,17,18,19,22,29]}$ reported high levels of student satisfaction with CBNL. However, this was not an outcome measure in two studies ${ }^{[4,5]}$. Students in four studies ${ }^{[14,18,22,29]}$ felt very motivated to learn by using CBNL. Nevertheless, students identified some problems related to wireless connectivity, computers and user support in four studies ${ }^{[12,14,19,29]}$.

\section{Discussion}

\subsection{Review strengths and weaknesses}

Although we selected a total of nine papers, the integrative review suffers from several limitations. We excluded those studies evaluating the use of CBNL for clinical skills education in the context of staff nursing education ${ }^{[9]}$ or graduate nursing education ${ }^{[7,16,25,28,33,34]}$, or evaluating perceptions ${ }^{[20,23]}$ in online nursing education. Moreover, we also excluded studies reporting the use of simulators ${ }^{[26,35]}$ and games in nursing education. We also preferred to include studies that are not completely rigorous and systematic, rather than omitting any relevant study. For example, the study by Kenny et al. ${ }^{[19]}$ had important limitations.

Since other review articles ${ }^{[6,21]}$ have addressed the studies corresponding to the time slot 1966-2006, in our research work we have covered the time slot 2007-2010 in order to gain insight into what the next steps taken in this field have been. In 
paper ${ }^{[8]}$, the authors only analysed qualitative data according to the student experience (satisfaction, enjoyment and perspectives) whereas we have analysed both qualitative and quantitative data.

\subsection{Strength of evidence}

Nine studies met the inclusion criteria and were selected and analysed for this review. The studies are spread across five continents, the majority being from Europe. This could perhaps be explained by the importance of such studies in this continent, along with the development of the new European Higher Education Area.

Some of the design weaknesses identified in earlier articles ${ }^{[6,21]}$ have been corrected in the studies discussed here. With the exception of two articles ${ }^{[18,19]}$, all of the other studies involved sample sizes which were higher than 70 . All of the studies used a post-test, and seven of them reported the use of a pre-test. In order to minimize bias, eight studies used randomized experimental designs to allocate control and experimental groups. Furthermore, all researchers used comparative groups. The studies involved up to ten nursing clinical skills. The potential of the multimedia technology applied to procedural nursing skills learning led videos to be the most frequently used e-learning materials.

In contrast, the papers studied did not address several important issues. In the nursing education context, it is crucial to identify and document any factor associated with the problems of knowledge and clinical skills retention ${ }^{[6]}$. However, only two studies ${ }^{[4,5]}$ evaluated skill or cognitive retention. These studies found a serious problem in the high dropout rate between different measuring points, thus endangering the statistical results. Note that when participation in the study was voluntary, e-learning sessions were additional to scheduled classes, on top of an already heavy study-load ${ }^{[5,19]}$.

Variations related to the students' characteristics may have affected the composition of the experimental and comparative groups, thus having an effect on the interpretation of the statistical results. It is therefore essential to control such variations to decrease the risk of bias. Although eight studies reported on demographics, five studies ${ }^{[4,12,18,19,29]}$ did not perform an analysis of confounding factors. Three studies ${ }^{[5,14,17]}$ carried out analyses, and did not find significant differences in age and grade point average between the experimental and control groups. Only one study ${ }^{[22]}$ found statistically significant differences in the academic grades. Two studies ${ }^{[5,14]}$ did not report significant differences in the students' experience with computers. Another point to note is that only two studies ${ }^{[5,18]}$ involved first-year nursing students. The environment and the participants' others circumstances such as lifestyle factors may also have affected learning.

Other potential sources of bias found in the studies reviewed are the unequal instruction time for different study groups, and the variations in the time that elapsed between instruction and testing-from one day ${ }^{[17]}$ to eight weeks ${ }^{[5]}$. Note that only two studies presented an experiment in which participants in both the experimental and control group received equal instruction time, one hour ${ }^{[4]}$ and 90 minutes ${ }^{[5]}$.

The fact that the participants were able to take part in some studies on a voluntary basis ${ }^{[4,5,14,18,19]}$ may have caused self-selection bias. Note that the students in these groups may have preferred the CBNL style, which may have contributed to the positive results in these studies. This may have been a possible threat to the validity of the experiments.

In one study ${ }^{[22]}$, only one evaluator conducted skill evaluation, so the potential assessor subjectivity could have contributed to the score differences observed, although he used a standardized checklist. When two or more assessors were involved in the experiments, both the inter-observer and intra-observer reliability were determined in only two studies ${ }^{[4,5]}$. This may have threatened the validity and reliability of the measuring tool.

\subsection{I mplications of the review findings}

Three main obstacles prevent substantive evidence from being derived from a review related to the application of ICTs in nursing education ${ }^{[21]}$ : 
- Intra-study variability. Many factors affect nursing clinical skills learning in a computer-assisted context: age, previous knowledge, preferred learning style.

- Inter-study variability. The highly specific nature of most studies such as the course clinical skills, study design and the type of online resource make it difficult to synthesize findings from the individual studies.

- Cutting-edge technologies. The rapid evolution of technology may alter teachers' and students' expectations.

If these barriers are to be overcome, it is essential to conduct and replicate the designed studies in a rigorous manner. With this aim in mind, studied should follow some guidelines:

- Design a randomized controlled trial. Avoid voluntary recruitment.

- Test for differences in the demographic characteristics of participants in the study groups, especially, grade point average and the students' experience with computers. If differences are found, control them when data is analysed.

- Gather several pre-test and post-test measures at different times during the study ${ }^{[13]}$. The first pre-test should be repeated immediately after the instruction session in both groups.

- Ensure a suicient sample size for meaningful statistical analysis. Undertake a sample size calculation for a definitive trial.

- Create both an experimental and a control group.

- Use equal instruction time for different study groups. Moreover, students should be given enough time and a complete training session to understand the computerised technology employed.

- Evaluate both the students' knowledge and their knowledge retention at a distant time period.

- Skills performance should be evaluated by two or more assessors. Evidence of content validity for instruments should be provided ${ }^{[27]}$.

- Employ standardized outcome measures.

- Ensure that students have access to a fully equipped and well supported computer unit.

- Test a particular clinical skill and not a set of skills at the same time.

\section{Conclusions}

CBNL in nursing has been widely evaluated and investigated in recent years. Many studies in literature have reported that nursing education may benefit from the use of the information technologies, but evidence to support CBNL is limited. We identified important weaknesses in designs such as longitudinal follow-up and control of confounding variables in the studies reviewed. Most of the studies focus on investigating users' satisfaction and knowledge acquisition, while few studies address clinical skills and knowledge retention. Evaluation of innovative learning methods, with a strong focus on rigorous research methods, applied to a wider range of clinical skills, is necessary. All these issues reinforce the need for further research in this important area.

Researchers should also cast their eyes forward to future trends in education, paying particular attention to the impact of cloud-based applications, handheld portable devices and possible scenarios afforded by mobile technology. Cloud computing especially relies on a number of existing technologies, e.g., the Internet, virtualisation and grid computing, and will probably have a significant impact on teaching and learning environments ${ }^{[11,32]}$. With the proliferation of tools supporting emerging technologies, the study of the effectiveness of these new tools will be necessary. 
Table 3. Summary table

What was already known on the topic?
- CBNL in nursing has been widely evaluated and investigated in recent years
What this study has added to our knowledge?
- The studies reviewed have important weaknesses in designs such as longitudinal follow-up and control of confounding
variables
Most of the studies focus on investigating users' satisfaction and knowledge acquisition, while few studies address clinical
skills and knowledge retention

\section{References}

[1] M Adams A. Pedagogical underpinnings of computer-based learning. J Adv Nurs. 2004; 46(1): 5-12. PMid:15030437 http://dx.doi.org/10.1111/j.1365-2648.2003.02960.x

[2] Ainsley B, Brown A. The Impact of Informatics on Nursing Education: A Review of the Literature. The Journal of Continuing Education in Nursing. 2009; 40(5): 228-32. http://dx.doi.org/10.3928/00220124-20090422-02

[3] Al-Jewair TS, Qutub AF, Malkhassian G, Dempster LJ. A systematic review of computer-assisted learning in endodontics education. J Dent Educ. 2010; 74(6): 601-11. PMid:20516299

[4] Beeckman D, Schoonhoven L, Boucqu H, Maele GV, Defloor T. Pressure ulcers: e-learning to improve classification by nurses and nursing students. J Clin Nurs. 2008; 17(13):1697-707. PMid:18592624 http://dx.doi.org/10.1111/j.1365-2702.2007.02200.x

[5] Bloomfield J, Roberts J, While A. The effect of computer-assisted learning versus conventional teaching methods on the acquisition and retention of handwashing theory and skills in pre-qualification nursing students: a randomised controlled trial. Int $\mathrm{J}$ Nurs Stud. 2010; 47(3): 287-94. PMid:19762016

[6] Bloomfield JG, While AE, Roberts JD. Using computer assisted learning for clinical skills education in nursing: integrative review. J Adv Nurs. 2008; 63(3): 222-35. PMid:18702768 http://dx.doi.org/10.1111/j.1365-2648.2008.04653.x

[7] Campbell M, Gibson W, Hall A, Richards D, Callery P. Online vs. face-to-face discussion in a web-based research methods course for postgraduate nursing students: a quasi-experimental study. International Journal of Nursing Studies. 2008; 45(5): 750-9. PMid:17306272 http://dx.doi.org/10.1016/j.ijnurstu.2006.12.011

[8] Carroll C, Booth A, Papaioannou D, Sutton A, Wong R. UK health-care professionals' experience of on-line learning techniques: a systematic review of qualitative data. J Contin Educ Health Prof. 2009; 29(4):235-41. PMid:19998474 http://dx.doi.org/10.1002/chp.20041

[9] Chang W-Y, Sheen STH, Chang PC, Lee PH. Developing an e-learning education programme for staff nurses: Processes and outcomes. Nurse Education Today. 2008; 28(7):822-8. PMid:18384917 http://dx.doi.org/10.1016/j.nedt.2008.02.003

[10] Childs S., Blenkinsopp E, Hall A, Walton G. Effective e-learning for health professionals and students-barriers and their solutions. A systematic review of the literature-findings from the hexl project. Health Info Libr J. 2005; 22 Suppl 2: 20-32. PMid:16279973 http://dx.doi.org/10.1111/j.1470-3327.2005.00614.x

[11] Ercan T. Effective use of cloud computing in educational institutions. Procedia - Social and Behavioral Sciences. 2010; 2(2): 938-942.

[12] Farrell MJ, Rose L. Use of mobile handheld computers in clinical nursing education. J Nurs Educ. 2008; 47(1):13-19. PMid:18232610 http://dx.doi.org/10.3928/01484834-20080101-03

[13] Fox MT, Brathwaite AC, Sidani S. Evaluating the effectiveness of interventions: exploration of two statistical methods. Can J Nurs Res. 2004; 36(3): 20-30. PMid:15551660

[14] Gerdprasert S, Pruksacheva T, Panijpan B, Ruenwongsa P. Development of a Web-Based Learning Medium on Mechanism of Labour for Nursing Students. Nurse Education Today. 2010; 30(5): 464-9. PMid:19931950 http://dx.doi.org/10.1016/j.nedt.2009.10.007

[15] Glen S. E-learning in nursing education: Lessons learnt? Nurse Educ Today. 2005; 25(6): 415-7. PMid:16054949 http://dx.doi.org/10.1016/j.nedt.2005.07.001

[16] Horiuchi S, Yaju Y, Koyo M, Sakyo Y, Nakayama K. Evaluation of a web-based graduate continuing nursing education program in japan: A randomized controlled trial. Nurse Educ Today. 2009; 29(2): 140-9. PMid:18829141 http://dx.doi.org/10.1016/j.nedt.2008.08.009

[17] Kaveevivitchai C, Chuengkriankrai B, Luecha Y, Thanooruk R, Panijpan B, Ruenwongsa P. Enhancing nursing students' skills in vital signs assessment by using multimedia computer-assisted learning with integrated content of anatomy and physiology. Nurse Education Today. 2009; 29(1): 65-72. PMid:18703258 http://dx.doi.org/10.1016/j.nedt.2008.06.010 
[18] Kelly M, Lyng C, McGrath M, Cannon G. A multimethod study to determine the effectiveness of, and student attitudes to, online instructional videos for teaching clinical nursing skills. Nurse Education Today. 2009; 29(3, Sp. Iss. SI): $292-300$.

[19] Kenny RF, Park CL, Van Neste-Kenny JMC, Burton PA, Meiers J. Mobile learning in nursing practice education: Applying Koole's FRAME model. Journal of Distance Education. 2009; 23(3): 75-96.

[20] Langley ME, Brown ST. Perceptions of the use of reflective learning journals in online graduate nursing education. Nursing Education Perspectives. 2010; 31(1): 12-7. PMid:20397474

[21] Lewis MJ, Davies R, Jenkins D, Tait MI. A review of evaluative studies of computer-based learning in nursing education. Nurse Educ Today. 2001; 21(1): 26-37. PMid:11162255 http://dx.doi.org/10.1054/nedt.2000.0494

[22] Lu DF, Lin ZC, Li YJ. Effects of a Web-Based Course on Nursing Skills and Knowledge Learning. Journal of Nursing Education. 2009; 48(2): 70-7. PMid:19260398 http://dx.doi.org/10.3928/01484834-20090201-10

[23] Mancuso JM.. Perceptions of distance education among nursing faculty members in North America. Nursing \& Health Sciences. 2009; 11(2): 194-205. http://dx.doi.org/10.1111/j.1442-2018.2009.00456.x

[24] Liberati A, Altman DG, Tetzlaff J, Mulrow C, Gøtzsche PC, Ioannidis JP, et al. The PRISMA statement for reporting systematic reviews and meta-analyses of studies that evaluate health care interventions: explanation and elaboration. Journal of Clinical Epidemiology. 2009; 62(10): e1-34. PMid:19631507 http://dx.doi.org/10.1016/j.jclinepi.2009.06.006

[25] Padalino Y, Helena H, Peres C. E-learning: a comparative study for knowledge apprehension among nurses. Revista Latino-Americana de Enfermagem. 2007; 15(3): 397-403. PMid:17653421 http://dx.doi.org/10.1590/S0104-11692007000300006

[26] Paige JT, Kozmenko V, Yang T, Gururaja RP, Hilton CW, Cohn I Jr, Chauvin SW. Attitudinal changes resulting from repetitive training of operating room personnel using of high-fidelity simulation at the point of care. American Journal of Surgery. 2009; 75(7): 584-90; discussion 590-1.

[27] Polit DF, Beck CT, Owen SV. Is the CVI an acceptable indicator of content validity? Appraisal and recommendations. Res Nurs Health. 2007; 30(4): 459-67. http://dx.doi.org/10.1002/nur.20199

[28] Raynor M, Iggulden H. Online anatomy and physiology: piloting the use of an anatomy and physiology e-bookVLE hybrid in pre-registration and post-qualifying nursing programmes at the University of Salford. Health Information \& Libraries Journal. 2008; 25(2): 98-105. PMid:18494644 http://dx.doi.org/10.1111/j.1471-1842.2007.00748.x

[29] Reime MH, Harris A, Aksnes J, Mikkelsen J. The most successful method in teaching nursing students infection control E-learning or lecture? Nurse Education Today. 2008; 28(7): 798-806. PMid:18442872 http://dx.doi.org/10.1016/j.nedt.2008.03.005

[30] Sheridan C, Gorman T, Claffey N. Dental nursing education and the introduction of technology-assisted learning. Eur J Dent Educ. 2008; 12(4): 225-32. PMid:19021729 http://dx.doi.org/10.1111/j.1600-0579.2008.00523.x

[31] Simpson RL. See the Future of Distance Education. Nursing Management. 2006; 37(2): 42-51. http://dx.doi.org/10.1097/00006247-200602000-00012

[32] Sultan N. Cloud computing for education: A new dawn? International Journal of Information Management. 2010; 30(2):109-16. http://dx.doi.org/10.1016/j.ijinfomgt.2009.09.004

[33] Sung YH, Kwon IG, Ryu E. Blended learning on medication administration for new nurses: Integration of e-learning and face-to-face instruction in the classroom. Nurse Education Today. 2008; 28(8): 943-52. PMid:18599162 http://dx.doi.org/10.1016/j.nedt.2008.05.007

[34] Tait M, Tait D, Thornton F, Edwards M. Development and evaluation of a critical care e-learning scenario. Nurse Education Today. 2008; 28(8): 970-80. PMid:18603339 http://dx.doi.org/10.1016/j.nedt.2008.05.016

[35] Tsai SL, Chai SK, Hsieh LF, Lin S, Taur FM, Sung WH, Doong JL. The use of virtual reality computer simulation in learning Port-A cath injection. Advances in Health Sciences Education. 2008; 13: 71-87. PMid:16944000 http://dx.doi.org/10.1007/s10459-006-9025-3 